\title{
PAY EQUITY AND EQUAL EMPLOYMENT OPPORTUNITY: POLICY, RHETORIC AND REALITY IN THE 2004 NEW ZEALAND LABOUR MARKET
}

\author{
Prue Hyman \\ Gender and Women's Studies \\ Victoria University of Wellington
}

\begin{abstract}
Pay equity (here interpreted as equal pay for work of equal value) has long been official Labour Party policy, although never properly implemented. The recent Taskforce on Pay and Employment Equity in the Public Service, Public Education and Public Health proposes advances in those sectors. At the same time, Part Two of the Employment Relations Law Reform Bill a First Reading Stage would have repealed the only possible, if disputed, legislative underpinning for equal pay for work of equal value in the public and private sectors. After submissions and lobbying, the government sensibly agreed to the Select Committee recommendation to withdraw this from the Bill. The HRC report "Framework for the Future: Equal Employment Opportunities in New Zealand" finds little progress in the employment position of people with disabilities, while the status of Pacific people in the New Zealand labour force is even worse than that of Maori - nor has gender equality yet been achieved. It argues that a lack of equal opportunity creates social tension while New Zealand is being held back economically through talent being under-utilised. This paper will discuss these reports and developments, government policy and the realities in these areas in 2004 New Zealand.
\end{abstract}

\section{A Year of Reports}

More information and reports on pay equity and equal employment opportunity (henceforth EEO) have been released in 2004 than for many a year, although this does not yet equate to real action. Much of the material recycles and updates earlier documents, sometimes reinventing the wheel. Nevertheless, with progress on actual implementation so slow and dependent on political commitment, stocktakes are necessary. This paper discusses these reports and developments, government policy on EEO and pay equity, and on-the-ground realities in the 2004 New Zealand labour market. It focuses mainly on gender issues, but touches on other dimensions of EEO, particularly ethnicity and disability. It also discusses the links between the gender pay gap, pay equity, and low paid work.

On changes of emphasis with respect to EEO in the labour market, a greater range of groups rightly receive increasing attention, including new migrants, older workers, and a full range of ethnicities. Probably the most fashionable area of EEO is advancing the principle of the family friendly workplace and finding a work life balance, which could theoretically increase gender equity and improve the quality of life of both women and men and their children (NZDOL, 2004; NZCTU, 2004). Implementation is another matter - increased dispersion in the numbers of weekly hours worked is evident, with large numbers of employees working very long hours, which are anything but family friendly (Callister, 2004). Among professional and managerial workers, long hours are often perceived to be needed and to indicate commitment to career and the enterprise - and are dependent on a partner doing the bulk of the family caring work. With gender neutrality anything but achieved in this area, this acts as a break on the careers of many women. And for many lower paid, casualised and part time workers, several jobs amounting to a total week of long hours are needed to earn a living wage - if jobs which fit can be found. While the numbers in labour force surveys who indicate they are underemployed, seeking more weekly hours, has declined, the total is still high.

Some changes of emphasis are evident in justifications of employment equity, with ever increasing concern for efficient use of human resources stressed alongside or even ahead of fairness and human rights. But the main arguments made by proponents and opponents, including the economic ones and the ideological positions underpinning them, remain largely unchanged. Thus there is strong political and business resistance to anything seen to impede employer autonomy and labour market flexibility and/or impose compliance costs.

One benefit from the many 2004 reports is more qualitative and case study information, particularly in the projects commissioned by the Taskforce on Pay and Employment Equity in the Public Service, Public Education and Public Health (henceforth in this paper, Taskforce). Many of the project reports were summarised in papers for the Conference on Pay and Employment Equity for Women, organised by the National Advisory Council on the Employment of Women in June (and available from its website, http://www.nacew. govt.nz /conference2004/papers.html). This conference also invited speakers from Canada, England, Australia, and the United States, who suggested important lessons from their experience. Canada in particular has advanced employment equity on many fronts, and an impressive recent 500 page report for the Federal Government on pay equity gives some indication of how far behind New 
Zealand has slipped (Pay Equity Taskforce, 2004). The Canadian report's title: Pay Equity - a New Approach to a Fundamental Right" reflects its view that pay equity is a human right which needs its own legislation. "At the heart of the principle of equal pay for equal value is a concern with systemic discrimination, and with pay practices which have routinely overlooked or devalued important aspects of the work done by women" (ibid, p 150).

In accord with this view of pay equity, the Taskforce clearly identified its brief as covering equal pay for work of equal value as well as EEO and in theory at least obtained 'buy in' from government officials from all the key departments - although the officials did not endorse legislative means of achieving this. Thus the Taskforce stated that the overall principle of its proposed Action Plan is to ensure that in the state sector, pay is not affected by gender - "that is, women's and men's work of similar value is paid similarly" (Taskforce, 2004, p 11), and it defined its key terms as follows:

"Employment equity means the elimination of barriers to equality for women in employment. It involves implementing gender neutral policies and practices in access to employment opportunities, and in terms and conditions of employment, including pay. Pay equity means that women receive the same pay as men for the same work and for work which is different, but of equal value. Where women and men do quite different jobs, pay equity means equality of pay where skills, training, responsibility, effort and work conditions are assessed as comparable (without reference to gendered assumptions)" (ibid, p 11). Further, the Taskforce argued in terms of efficiency as well as equity, an argument with force in a tight labour market. "The scale and persistence of the gender pay gap in New Zealand reflects a failure in the 'market' which is not good for the economy or in the interests of the majority of employers or employees. The rewards are considerable for organisations that find ways to overcome barriers and constraints that currently limit the role and contribution of women" (ibid, p 11)."

\section{Equal Employment Opportunity}

The Human Rights Commission published in June 2004 a commissioned report on the status of EEO in New Zealand, with international comparisons of legislation, policy and practices (Mintrom and True, 2004). This found that among the key target groups, most progress has been made by women, but that even this "has been quite limited and equality with men in participation rates, pay, and seniority across occupations classes is a far-off goal" (Mintrom and True, 2004, p 8). Major gaps are identified on information about the position of people with disabilities, but it appears that "there has been little progress, if not regress" (ibid, p 8) in their employment position. And, while there has been some progress for Maori, all statistical indicators show ongoing disadvantage in the labour market, while the status of Pacific people in the New Zealand labour market is even worse.
There are also issues for other significant groups. Many migrants find they cannot obtain work commensurate with their skills, while older workers often face discrimination, particularly after redundancy (McGregor and Gray, 2001). With the age of superannuation raised to 65 and anti discrimination legislation preventing compulsory retirement based on age, labour force participation has risen substantially among the over 60 age group. However, it is clear from research and the extent of discrimination complaints received by the HRC that legislation is only a first step.

Mintrom and True's recommendations cover immediate and longer term actions. Noting that New Zealand practice has fallen behind that of comparable countries which have stronger legislation covering the private sector, it suggests that legislative underpinning combined with incentives is essential. Hence it recommends (in its long term list) legal requirements for EEO plans for all employers, starting with larger enterprises, proposals very similar to one part of the shortlived Employment Equity Act, 1990, repealed by National after only a few months of life. The need for such legislation seems evident from its discussion of the EEO Trust's survey of employers in 2002. Of its 373 members (the comparatively 'converted') $98.4 \%$ responded to questions about EEO policies, as against a meagre $5.3 \%$ of 3,340 non members. But of those responding. in both groups, the proportion reporting EEO policies in place were among the lowest since the survey began. Further, of the top 100 companies by turnover, only nine referred to anti discrimination practices, EEO policies, and/or the positions of women and other target groups in their most recent annual reports.

For the public sector, there is more information due to its statutory obligations. I concentrate here on the core public service, but the Taskforce covers also the public health and education sectors. Its report is strong on the inadequate implementation of requirements under the State Sector Act, 1988. This requires Public Service CEOs to operate as 'good employers' which inter alia involves a proactive Equal Employment Opportunities programme, covering at a minimum: Maori; women; ethnic minority groups; and persons with disabilities. However, "it is clear from the Taskforce's investigations that state sector organisations are unable to outline the extent of pay and employment equity among their employees, or the issues involved. Stronger mechanisms are required to ensure that the issues are not only identified, but also acted upon" (Taskforce, 2004, p 74).

The Taskforce's Action Plan includes measures to ensure that state sector organisations are provided with the tools and skills they need to identify and respond effectively to these problems. The gradual weakening of the State Services Commission's monitoring role in EEO has been among the factors contributing to the downplaying of real commitment and action in this area. Mainstreaming policy development and implementation is admirable in theory if it means adoption throughout an organisation, but in practice it can mean a lack of ownership and of skills and knowledge in the area, and thus become an excuse for inaction. 
The Taskforce recognised these issues and the need for real accountability, recommending that "the State Services Commissioner will, as part of his/her annual report, report on progress toward pay and employment equity in the public service and hold chief executives to account for the quality and clarity of their interventions to reduce pay and employment inequalities, and support innovative approaches" (ibid, p 74).

Taskforce projects considering which practices and policies have, and which have not, been effective in improving employment equity show that excellent EEO practices can and do make a difference. But there is often a false view that EEO has 'been done', (Jones and Torrie, 2004). The most frequently mentioned EEO issues for women are familiar ones. They include work/life balance issues (such as heavy workloads, long working hours and inflexible work arrangements), gender-based expectations of leadership and management style, a ceiling on career progression opportunities, and aspects of organisational culture. To make EEO workable requires a commitment at the top carried through the organisation, involving resourcing, incentives, and monitoring. For example, in analysing what works and what fails, success requires "designated specialist expertise in EEO policies and practices" rather than "leaving EEO to HR staff with little or no capability and many other responsibilities" and "reporting requirement which makes EEO strategies and outcomes transparent to all stakeholders: rather than "inconsistent and incomplete reporting which is not adequately collated analysed or reported" (ibid, p 14).

The Taskforce covered the content issues mentioned above with respect to EEO in its recommendations, calling for accessible, high quality, affordable childcare, support for users of care for dependants, improvements to paid parental leave and breastfeeding provisions, work life balance developments, removal of barriers to education and training, and attention to gender impacts of student loans and superannuation provisions. Building on its report should give a new impetus to strengthening EEO implementation in the public sector - extending this to the private sector by anything more than exhortation is a more intractable issue while the political commitment is lacking.

\section{Equal Pay for Work of Equal Value}

Equal pay for work of equal value remains a highly controversial principle. Where EEO is at least in theory widely supported, the notion that some types of female dominated work are (or even could be) undervalued by the market is viewed with suspicion in many quarters. Nevertheless, equal pay for work of equal value is central to both ILO Convention 100 and CEDAW, both of which New Zealand has ratified. While the Taskforce rightly saw this area as an integral part of their brief, it is clear that the current government envisages future progress as cautious, led by the public sector, and without further legislation. Public sector leadership may indeed be sensible on an issue where employers are strongly resistent. It is in the broad public sector where some progress has been made using equal value arguments in collective bargaining/court decisions - examples include midwives versus general practitioners for fees for normal birth and pay parity for primary teachers when equally qualified with secondary teachers. And the current nurses pay claim uses equal value arguments as part of their case.

Equal pay for work of equal value has long been Labour Party policy, in and out of government. However, some of its actions (and inaction) have raised questions about the strength of commitment, The treatment of equal pay in the Employment Relations Law Reform legislation is a salutary example in this connection. At introduction, Part Two would have repealed the Equal Pay Act 1972 and the Government Service Equal Pay Act 1960 and replaced them with a process covering equal pay for identical/substantially similar work only, considered a slight improvement on the current processes in this area by some commentators, but as grossly inadequate by others. Such individualised processes are widely judged to be inappropriate as the only mechanism in this area and are in any case already available under human rights and personal grievance procedures. Collective claims and a union role are needed. In addition, Part Two would have clearly ruled out the taking of equal pay for work of equal value claims. There are certainly problems with the 1960 and 1972 Acts in the current industrial relations environment and they would benefit from being updated, with few complaints or cases in recent years. However, their proposed repeal was regarded as a severe blow and unfortunate signal by proponents of equal value policies, many of whom have been loyal Labour supporters.

It was hard to understand such provisions being introduced while the Taskforce was in operation. Repeal was guaranteed to alienate many women's organisations which have been active in this area for decades. Arguing in favour of Part Two, Ministers and Department of Labour officials suggested that the 1960 and 1972 Acts either never covered equal pay for work of equal value or no longer do so, given case law and later legislative changes. The first is simply an incorrect reconstruction of history, while the second is strongly challenged (Orr, 1986, a and b, and 2004, Hyman, 1987 and 1993; Coleman, 1996).

Earlier Labour Governments accepted that the 1972 Act covered equal value, with their 1984/90 administration conducting studies about why it was not being achieved. As a result they initiated the short lived 1990 Employment Equity Act which attempted to cover the issue more adequately in the changed industrial relations environment. This was never activated beyond initial claims and was rapidly repealed by the incoming National government. Various factors, including the potential costs, actual and psychic, to complainants and their unions, have meant little use has been made of the 1972 Act in recent years. Unions have considered taking a case to challenge the negative judgement in the 1986 Clerical Workers claim and to test the legislation - and this idea has been recently revived.

This part of the Bill attracted little media attention. Hence, out of 354 substantive submissions and 7087 form submissions on the Bill, only 107 referred to this issue, 
showing a lack of interest or lack of knowledge in this area compared to the more contentious issues which received more coverage. However, according to the Transport and Industrial Relations Select Committee's Commentary on the Bill, of these 107 submissions, 71 were opposed to Part Two, 33 supported its intent, but not the means to achieving it, while only 3 submitters supported it. The Select Committee recommended withdrawal of Part Two, with the majority looking forward to the development of robust equal pay and pay equity provisions being introduced in the future. The government, which had been subject to intensive lobbying, accepted this recommendation.

The National Council of Women were among those welcoming the withdrawal of Part Two, hailing it as victory for women workers. It is somewhat ironic that many groups who fought for better legislation in the 1980 s, culminating in the shortlived 1990 Employment Equity Act, were put in the position of fighting for the status quo. With the Taskforce's Action Plan applying only to its sectors, repeal would have meant no underpinning even in principle for equal value in the private sector, putting New Zealand clearly in breach of international conventions.

The Taskforce's recommendations for advancing equal pay for work of equal value in its sectors included the following immediate actions:

The Department of Labour to oversee the development of a gender neutral job evaluation tool suitable for use in the public service, the public health sector and the public education sector.

A new Pay and Employment Equity Unit to be established in the Department of Labour with an associated Steering Group - one of its tasks being to oversee the design and implementation of an audit and response plan process in these sectors, developing and piloting a model for this purpose.

The Taskforce also envisaged broadening the coverage of policy through the wider public sector, including SOEs, to include contract compliance, and ultimately a possible extension to the private sector. There are significant difficulties facing pay equity or even proper implementation of equal pay for equal work, and these are more complex in the private sector. Some stem from the changes to industrial relations/pay settlement which were part of the more market/deregulation agendas of the 1980 s and 1990s under both major parties. A lack of knowledge of other people's pay, supported by privacy legislation, the trend away from collective bargaining to individual contracts, the removal of union rights, only marginally restored by the 1999 Labour led government, and overall widening differentials are all negative factors.

However, progress should be possible in the public sector, building on the Taskforce report. Minister of Women's Affairs Ruth Dyson said in several speeches that the government endorsed its main recommendations and was proceeding to implement them. The Unit in the Department of Labour has already been established, headed by Philippa Hall, an Australian with a long history of public service leadership in this area. Its priorities include the development of the gender neutral job evaluation tools and audit procedures. Beyond the public sector, proponents of pay equity have suggested ways of making progress on proactive methods of implementation, with and without legislation, including more widespread use of gender neutral remuneration audits. Such proposals include quite detailed methods of delivery combining human rights and employment rights frameworks (Hill, 2004).

\section{Low Pay, Pay Equity, and the Minimum Wage}

Despite the symbolic and actual importance of specific gender targetted policies, in most circumstances general issues and policies have greater impact on female incomes and gender earnings gaps than more direct approaches. With women over-represented among low paid employees, the Taskforce rightly attached importance to the links between low pay, the gender pay gap and gender equity. I undertook their project investigating these relationships (Hyman, 2004a). Low pay was defined as earnings below $\$ 12$ per hour, approximately $2 / 3$ of average earnings. In May 2003 $24.1 \%$ of men and $34.8 \%$ of women were low earners under this criterion, with the overall incidence of low pay in New Zealand at $29.3 \%$ towards the high end among OECD countries. The incidence was particularly high $(47.1 \%)$ among Maori women, with $10 \%$ reporting earnings below the minimum wage (then $\$ 8.50$, now $\$ 9$ ) and $45.9 \%$ among Pacific women. Part time work is heavily female and disproportionately low paid. Sixty one percent of those earning up to $\$ 10$ per hour in 2003 were part time, as against $38 \%$ of those earning above $\$ 10$ per hour ( $36 \%$ of those below $\$ 10,11 \%$ above for men).

Labour market differentials are widening throughout the English speaking world, including New Zealand. The orthodox economics rationale for increased differentials is that of required higher returns to scarce skills, with top salaries reflecting high productivity, responsibility, and performance in an increasingly complex and technologically advanced environment with international competition for these skills. However, the literature also questions these explanations (Hyman, 1999). Orthodox economic analysis assumes that the relationship of skill to productivity is clear, whereas a major body of feminist and sociological literature argues that skill evaluation is largely socially determined. With definition and assessment very much a social construct, the skills involved in many jobs can be undervalued or ignored. This is of course the key issue in the argument for equal pay for work of equal value for female dominated work (Cockburn, 1983; Hyman, 1994; Kusterer, 1978).

High levels of inequality are correlated internationally with low levels of unionisation and collective bargaining. New Zealand in the 1990s saw a sharp reduction in unionisation and in collective, and especially multi employer bargaining under the 1991 Employment Contracts Act (ECA), generally and particularly for women employees. Part time workers and female 
dominated areas of work in small workplaces had been collectively covered to a greater extent than in most overseas countries. Thus the widening pay gaps associated with these industrial relations changes have differential gender and ethnic implications. High levels of female unionisation and centralised bargaining are also strongly associated in cross country comparisons with a lower gender pay gap (Saar, 1992; Whitehouse, 1992; Blau and Kahn, 2003).

A Taskforce project showed clear links between collective bargaining and gender pay gaps in the public sector which retained higher levels of unionisation and collective bargaining than elsewhere. There is also still a large gender salary gap, with twice as many men as women in receipt of salaries over $\$ 80,000$, and twice as many women as men under $\$ 29,000$ (May and Lonti, 2004). These figures were based on 38 departments with varying levels of collective bargaining. Higher salaries on average, and larger gaps between average female and average male pay were associated with departments without collective bargaining. The authors suggest that government set parameters under which pay increases must be funded from current resources providing an incentive for a concentration of pay reward to the upper ends of the pay scales with smaller numbers and where women are not well represented. Decentralised bargaining structures, with individualised and discretionary pay setting, facilitates this. Further, there are no mechanisms for addressing any gender discrimination that may arise from these processes.

The level of the minimum wage has an important role in protecting lower waged workers, particularly when collective bargaining is weak. Its relativity to average wages has fluctuated widely over the years in New Zealand with extremes of 83 percent initially (in 1947) and 30 percent in 1984. Minimum wage rates have been raised more since 1999 under Labour led governments than in previous years but this has only partially restored relativities to a current rate of about 47 percent. Four recent increases took the level at April 2004 to $\$ 9$ per hour (Hyman, 2004b).

Four objectives were formally adopted in 2000 by government for consideration in the annual review of the minimum wage (fairness, protection of the vulnerable lowest paid, income distribution, and increasing work incentives). The Taskforce recommended that gender equity be an additional objective to be taken into account in each review. Noting that increasing the minimum wage would assist with narrowing the gender pay gap, it also proposed a minimum code for the state sector to include an increased minimum wage for the sectors it covered. It suggested further research analysing the nature of low paid employment and those performing it and the economic and social impacts of further increasing the minimum wage.

\section{The Gender Earnings Gap}

This gap is a major driver of pay and employment equity policies so thorough analysis is essential to good policy.
However, space precludes discussion here beyond two brief points and reference to some sources.

First, there are dangers involved in placing too much weight on one statistic - there are many measures of the gender gap, relevant in different contexts (Hyman, 2004a). Summarising relationships or differences between two distributions by just one measure is problematic, and averages must be seen alongside increasing dispersion. "There is clearly a need to move beyond reliance on measures of central tendency to observations across the full wage distribution and to investigate trends at disaggregated levels (such as within occupations or sectors)" (Whitehouse, 2003, p 119/121). When male average earnings may be falling and inequality among male earners rising, Whitehouse suggests that "it is only within the context of a concept of wage fairness that the pursuit of eradicating the gender pay has meaning and utility. Absolute gender pay equity could after all be achieved in a world of highly unequal and (for some) inadequate wages" (ibid).

Secondly, all measures of the gender pay gap in New Zealand and comparable countries have narrowed over the last thirty years which is welcome and reflective of both increased human capital among women and higher returns to such capital. However, some argue that all the remaining gaps can be explained by productivity differences and that gender discrimination in pay no longer exists, based on studies analysing econometrically productivity related components of the gap and/or its reduction. There are, however some issues involved in interpretation of such studies - measuring discrimination statistically is not straightforward (Hyman, 1994). Even these studies attribute part of the gap to vertical and horizontal occupational segregation indicating the need for EEO policies, but not pay equity. One such recent New Zealand study finds productivity related factors account for most of the gap in the public sector (Gosse and Ganesh, 2004), while others explain significant proportions of levels and changes in the gap (Dixon, 2000 and 2004). However, there are other econometric studies which still find gender and ethnic discrimination in New Zealand in actual earnings (Alexander, Genc and Jaforullah, 2004), as do some micro studies of parts of the labour market, for example among professionals and managers (McGregor, 2002). Certainly the Taskforce is convinced that there is still a pay equity policy issue, not just EEO issues, in my view correctly.

\section{Conclusions/Further Research}

Work to explain and reconcile the results of various studies on the earnings gap would be a useful contribution to debates on pay equity. However, given the plethora of studies and reports on pay and employment equity, in New Zealand and overseas, more practical development and piloting of means of implementation of pay and employment equity is more urgent, as envisaged by the Taskforce. 


\section{References}

Alexander, W.R.J., Genc, M. and Jaforullah, M. (2004). Wage gaps in New Zealand in the late 90 's, Paper for NACEW Conference on Pay and Employment Equity for Women, Wellington.

Blau, F.D. and Kahn, L.M. (2003). Understanding international differences in the gender pay gap. Journal of Labor Economics, 21/1, 146-165.

Callister, P. (2004). The future of work within households: Understanding household-level changes in the distribution of hours of paid work. Wellington: New Zealand Department of Labour.

Cockburn, C. (1983). Brothers - Male dominance and technological change. London: Pluto Press.

Coleman, M. (1996). The Equal Pay Act 1972: Back to the future? LLB (Honours) Thesis, Victoria University of Wellington.

Curtin, J. (1991). Women, trade unions and equal pay. Proceedings of Union/Tertiary Research Conference 4, 154-172.

Dixon, S. (2000). Pay inequality between men and women in New Zealand. Wellington: New Zealand Department of Labour, Occasional Paper 2000/1.

Dixon, S. (2004), Understanding reductions in the gender wage differential 1997-2003. Paper for NACEW Conference on Pay and Employment Equity for Women, Wellington.

Gosse, M. and Ganesh, S. (2004). The gender pay gap and the importance of job size: Evidence from the New Zealand Public Service. New Zealand Economic Papers, 38/1, 101-118.

Hill, L. (2004). Equal pay for work of equal value: Making human rights and employment rights laws work together. Social Policy Journal of New. Zealand, 21, 1-21.

Hyman, P. (1987), Equal pay study - Phase one report (with A. Clark and Urban Research Associates). Wellington: New Zealand Department of Labour.

Hyman, P. (1993). Equal pay for women after the Employment Contracts Act: Legislation and practice - the emperor with no clothes? New Zealand Journal of Industrial Relations, 18/1, 4457.

Hyman, P. (1994), Women and Economics: A New Zealand Feminist Perspective Wellington: Bridget Williams Books.

Hyman, P. (1999), Are widening labour market earnings differentials entirely/partly/not at all economically rational/justified/ inevitable? in (ed) P.S. Morrison, Proceedings of the Eighth Conference on Labour: Employment and Work Institute of Geography, Victoria University of Wellington $110-116$.

Hyman, P. (2004a) Low pay/pay equity project. Wellington: Taskforce on Pay and Employment Equity in the Public Service and Public Health and Public Education Sectors

Hyman, P. (2004b) Working for significant increases in the minimum wage - a useful strategy for gender pay equity? Women's Studies Association Conference 2003 Collected Papers and Presentations, 78-84.

Jones, D. and Torrie, R. (2004), What works, what doesn't: employment equity in the public sector. Paper for NACEW Conference on Pay and Employment Equity for Women, Wellington.

Kusterer, K. (1978). Know-how on the job: the important working knowledge of 'unskilled' worker. Boulder, Colorado: Westview Press.

McGregor, J. (2002). Rhetoric versus reality: A progress report on the rise of women's power in New Zealand. New Zealand Centre for Women and Leadership, Massey University, Working Paper $02 / 1$.

May, R. and Lonti, Z. (2004). The Impact of Current Pay Fixing Mechanisms on the Gender Pay Gap in New Zealand. Paper for NACEW Conference on Pay and Employment Equity for Women, Wellington.

McGregor, J. and Gray, L. (2001). Mature job-seekers in New Zealand. Palmerston North: Massey University.

Mintrom, M. and True, J. (2004), Framework for the future - Equal Employment Opportunities in New Zealand. Report for EEO Unit of Human Rights Commission: Auckland.

New Zealand Council of Trade Unions (2004). It's about time: A Union guide to work-life balance. Wellington: NZCTU.

New Zealand Department of Labour (2004). Achieving balanced lives and employment - What New Zealanders are saying about work-life balance. Wellington: NZDOL Work Life Balance Project.

Orr, E. (1986a). The Arbitration Court's role in supervising the Equal Pay Act 1972 in Proceedings of Seminar on Equal Pay. Centre for Continuing Education, Victoria University of Wellington.

Orr, E. (1986b). The equal pay scene revisited, unpublished paper.

Orr. E. (2004). Equal pay for work of equal value, Women's Studies Association Conference 2003 Collected Papers and Presentations, 154-163.

Pay Equity Task Force (2004). Pay Equity: a new approach to a fundamental right. Final Report: Ottawa, Canada.

Saar, P. (1992). Out of the chorus line - the progress of women in New Zealand Unions. Wellington: New Zealand Council of Trade Unions.

Taskforce on Pay \& Employment Equity (2004). Report on Pay and Employment Equity in the Public Service and the Public Health and Public Education Sectors. Wellington.

Whitehouse, G. (1992), Legislation and labour market gender inequality: an analysis of OECD Countries. Work, Employment and Society 6/1, 65-86.

Whitehouse, G. (2003). Gender and pay equity: future research directions. Asia Pacific Journal of Human Resources, 41/1, 116-128. 